\title{
Pedobacter glucosidilyticus sp. nov., isolated from dry riverbed soil
}

Correspondence

Chengxiang Fang

cxfang@whu.edu.cn

\author{
Xuesong Luo, Zhang Wang, Jun Dai, Lei Zhang, Jun Li, Yali Tang, \\ Yang Wang and Chengxiang Fang
}

College of Life Sciences, Wuhan University, Wuhan 430072, PR China
At the time the family Sphingobacteriaceae and the genus Pedobacter were proposed by Steyn et al. (1998), the genus comprised only four recognized species: Pedobacter heparinus, Pedobacter piscium, Pedobacter africanus and Pedobacter saltans. Many novel species have been recovered from various environments and, at the time of writing, the genus Pedobacter contained 26 recognized species (Steyn et al., 1998; Margesin et al., 2003; Shivaji et al., 2005; Vanparys et al., 2005; Gallego et al., 2006; Hwang et al., 2006; Ten et al., 2006; Baik et al., 2007; Kwon et al., 2007; Muurholm et al., 2007; Yoon et al., 2006, 2007a, b, c, d; An et al., 2009; Roh et al., 2008; Lee et al., 2009). The description of the genus Pedobacter has also been emended recently (Vanparys et al., 2005; Gallego et al., 2006; Hwang et al., 2006).

In the course of a study of the cultivable microbial community of Tibet, China, a soil sample was collected from a dry riverbed in the Xietongmen area and used as a source for the isolation of bacterial strains. Over 50 colonies were isolated by means of the standard dilution plating technique at $28{ }^{\circ} \mathrm{C}$ on plates of 10 -fold diluted tryptic soy agar (TSA, Difco). All strains were preserved as lyophilized cultures. Two cream to pink coloured, raised, translucent and slimy colonies developed on the plates inoculated with the terminal dilutions of the soil

The GenBank/EMBL/DDBJ accession number for the 16S rRNA gene sequence of strain $1-2^{\top}$ is EU585748.

A light micrograph of cells of strain $1-2^{\top}$ is available as supplementary material in the online version of this paper. suspension. They were picked up and purified and were designated strains $1-2^{\mathrm{T}}$ and $1-4$. The strains were routinely grown on $0.1 \times \mathrm{TSA}$ at $28{ }^{\circ} \mathrm{C}$. Bacterial cells were observed by light and phase-contrast microscopy (BX51; Olympus) to ascertain their morphology. Gliding motility was assessed as described previously (Bowman, 2000). Cells were Gram-staining-negative, non-motile rods that occurred singly or in chains (see Supplementary Fig. S1 available at IJSEM online).

The genomic DNA of strains $1-2^{\mathrm{T}}$ and 1-4 was isolated using a bacteria genomic kit (CASarray Co., Ltd). The fragments comprising the $16 \mathrm{~S}$ rRNA gene were amplified by PCR using the primers described by Lane (1991). The PCR products were sequenced by Invitrogen Corporation and the 16S rRNA gene sequences (1386 bp) of the two strains were obtained. The identification of phylogenetic neighbours and the calculation of 16S rRNA gene sequence similarity were accomplished using the NCBI BLAST and the EzTaxon (http://www.eztaxon.org/; Chun et al., 2007) servers.

The two strains shared $100 \% 16 \mathrm{~S}$ rRNA gene sequence similarity and showed the highest sequence similarity, $94.2 \%$, with Pedobacter daechungensis Dae $13^{\mathrm{T}}$, followed by Pedobacter lentus KCTC $12875^{\mathrm{T}}(93.2 \%)$. Sequence similarity with all other species of the genus Pedobacter was $<93 \%$. Phylogenetic trees were constructed using the neighbour-joining and maximum-parsimony methods and the Kimura two-parameter model in MEGA version 3.1 (Kumar et al., 2004). The topology of the phylogenetic tree 
was evaluated by using the bootstrap resampling method with 1000 replicates. The new taxon formed a distinct branch within the genus Pedobacter in the neighbourjoining tree (Fig. 1). The maximum-parsimony tree showed essentially the same topology (data not shown).

Growth at 5, 15, 28, 30, 32, 37, 42 and $45{ }^{\circ} \mathrm{C}$, at pH 5.5, 6, 7, 8, 9, 9.5, 10, 10.5 and 11 (adjusted using $0.1 \mathrm{M} \mathrm{HCl}$ and $\mathrm{NaOH}$ and sterilized through a $0.2 \mu \mathrm{m}$ filter) and in the presence of $0,0.5,1,2,3$ and $5 \% \mathrm{NaCl}(\mathrm{w} / \mathrm{v})$ was assessed using $0.1 \times$ tryptic soy broth (TSB, Difco) as the basal medium. Growth on MacConkey agar was also tested. Flexirubin pigments were detected by means of a colour shift after exposure to a $20 \%(\mathrm{w} / \mathrm{v}) \mathrm{KOH}$ solution (Reichenbach, 1992). Catalase and oxidase activities and hydrolysis of starch, casein, tyrosine and Tween 40 were assessed as described by Smibert \& Krieg (1994) using $0.1 \times$ TSA as the basal medium. Heparinase activity was detected as described previously (Zimmermann et al., 1990). The utilization of various compounds as sole carbon sources was tested using Biolog GN2 MicroPlates (Biolog) in accordance with the manufacturer's instructions. The plates were incubated at $30{ }^{\circ} \mathrm{C}$ for $48 \mathrm{~h}$ and scored with a microplate reader using Microlog 4.2 computer software for automated reading. P. lentus KCTC $12875^{\mathrm{T}}$, Pedobacter terricola KCTC $12876^{\mathrm{T}}$ and $P$. daechungensis KCTC $12637^{\mathrm{T}}$ were used as reference strains and studied in parallel with strains $1-2^{\mathrm{T}}$ and $1-4$ using API 20NE, API 20E, API 50CH and API ZYM strips (bioMérieux) according to the manufacturer's instructions.

Based on physiological and biochemical properties, strains $1-2^{\mathrm{T}}$ and 1-4 showed characteristics consistent with the original and emended descriptions of the genus Pedobacter (Steyn et al., 1998; Vanparys et al., 2005; Gallego et al., 2006; Hwang et al., 2006). The few discrepancies that were noted between the two novel isolates, and the phenotypic characteristics that differentiated them from their closest phylogenetic neighbours are shown in Table 1.

For cellular fatty acid analysis, strain $1-2^{\mathrm{T}}$, P. terricola KCTC $12876^{\mathrm{T}}$ and $P$. daechungensis KCTC $12637^{\mathrm{T}}$ were grown on R2A agar (Difco) for $72 \mathrm{~h}$ at $30{ }^{\circ} \mathrm{C}$. The cellular fatty acids were extracted, esterified and analysed by GC (6890N; Agilent) according to the instructions of the Sherlock Microbial Identification System (MIDI). The fatty acid pattern of strain $1-2^{\mathrm{T}}$ was consistent with those of other species of the genus Pedobacter; the quantitative

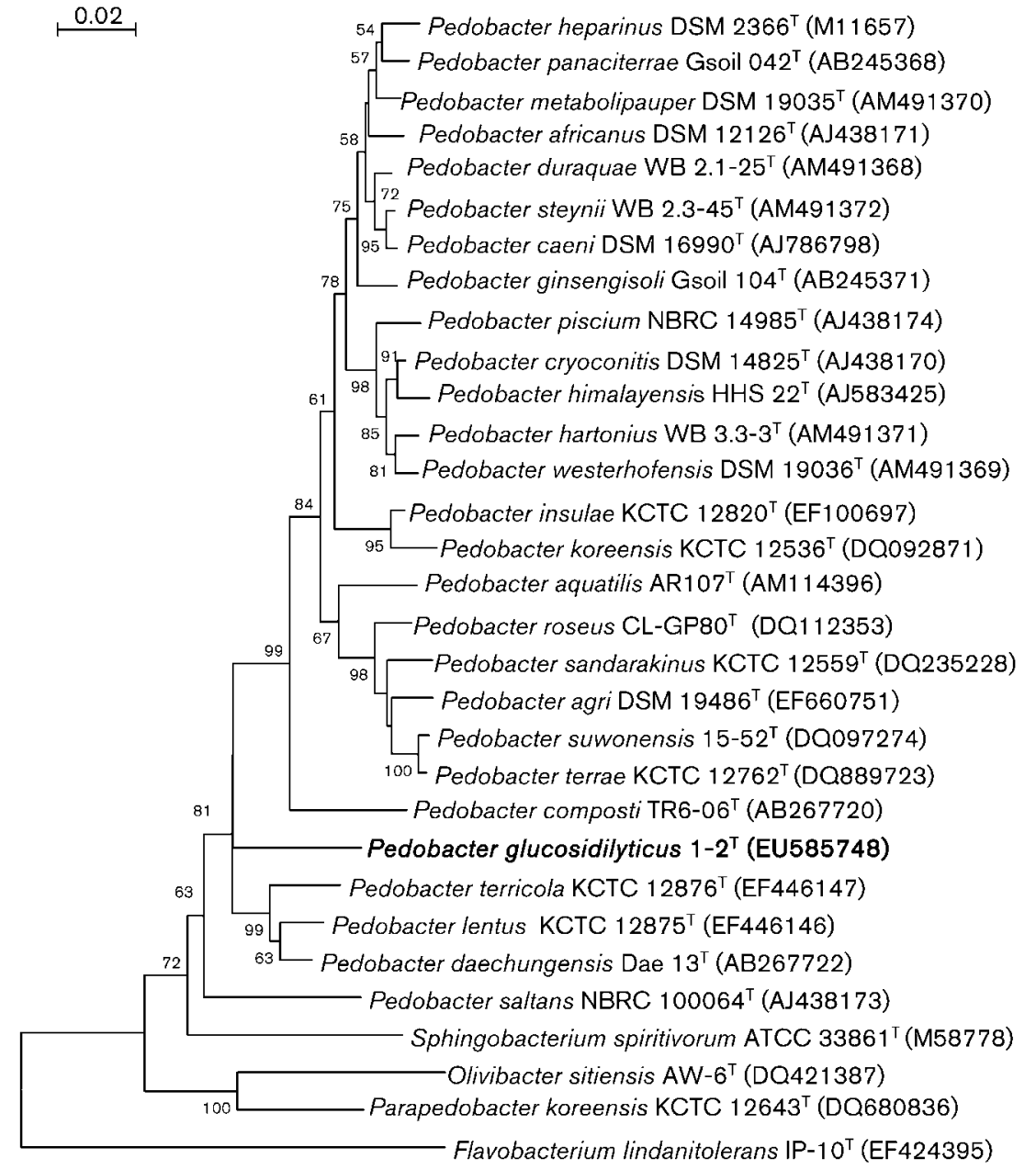

Fig. 1. Neighbour-joining phylogenetic tree showing the relationship between strain $1-2^{\top}$, other species of the genus Pedobacter and representatives of related taxa. Numbers at branch nodes are bootstrap values based on 1000 resamplings; only values $>50 \%$ are given. Flavobacterium lindanitolerans $\mathrm{IP}-10^{\top}$ was used as the outgroup. Bar, 0.02 substitutions per nucleotide position. 
Table 1. Differential characteristics of strain $1-2^{\top}, 1-4$ and phylogenetically related species of the genus Pedobacter

Taxa: 1, strains $1-2^{\mathrm{T}}$ and 1-4; 2, Pedobacter lentus KCTC $12875^{\mathrm{T}} ; 3$, P. terricola KCTC $12876^{\mathrm{T}}$; 4, P. daechungensis KCTC $12637^{\mathrm{T}}$. All API data are from this study. All strains are positive for the following characteristics: hydrolysis of aesculin, activities of catalase, oxidase, alkaline phosphatase, esterase (C4), esterase lipase (C8), leucine arylamidase, $\alpha$-glucosidase (except $P$. daechungensis), valine arylamidase, cystine arylamidase, acid phosphatase and naphthol-AS-biphosphohydrolase, acid production from maltose, D-mannose, L-arabinose, D-xylose, D-galactose (only $P$. daechungensis was negative for acid production from the above sugars) and D-glucose, and for susceptibility to chloramphenicol and tetracycline. All strains are negative for the following characteristics: production of $\mathrm{H}_{2} \mathrm{~S}$ and indole, nitrate reduction, activities of urease, arginine dihydrolase, $\beta$-glucuronidase, trypsin, $\alpha$-chymotrypsin, $\alpha$-galactosidase and $\alpha$-mannosidase, acid production from erythritol, ribose, adonitol, inulin, raffinose, inositol, D-sorbitol, turanose, L-fucose, D-lyxose, D-fucose, L-arabitol, D-arabitol, 2-ketogluconate, L-xylose and mannitol. +, Positive; -, negative; $\mathrm{W}$, weakly positive; $\mathrm{V}$, variable (i.e. variable results between different strains of the same species or variable results observed in three independent experiments).

\begin{tabular}{|c|c|c|c|c|}
\hline Characteristic & 1 & 2 & 3 & 4 \\
\hline Colony colour & Cream to pink & Pale yellow to pale orange & Pale orange & Reddish orange \\
\hline Maximum growth temperature $\left({ }^{\circ} \mathrm{C}\right)$ & 37 & 31 & 34 & 30 \\
\hline$N$-Acetyl- $\beta$ glucosaminidase & + & + & + & - \\
\hline$\alpha$-Fucosidase & + & - & - & - \\
\hline$\beta$-Galactosidase & $\mathrm{w}$ & + & + & - \\
\hline Lipase & $\mathrm{W}$ & - & - & $\mathrm{w}$ \\
\hline \multicolumn{5}{|l|}{ Acid from (API 50CH) } \\
\hline$N$-Acetylglucosamine & + & - & - & - \\
\hline Amygdalin & + & - & + & - \\
\hline Arbutin & + & - & - & - \\
\hline Cellobiose & + & - & + & + \\
\hline Melibiose & $\mathrm{W}$ & - & - & - \\
\hline Methyl $\alpha$-D-glucopyranoside & $\mathrm{v}$ & $\mathrm{v}$ & $\mathrm{w}$ & - \\
\hline Methyl $\alpha$-D-mannopyranoside & $\mathrm{V}$ & - & - & - \\
\hline Methyl $\alpha$-D-xylopyranoside & - & - & + & - \\
\hline L-Rhamnose & $\mathrm{W}$ & $\mathrm{W}$ & $\mathrm{W}$ & - \\
\hline Salicin & + & - & - & - \\
\hline L-Sorbose & - & + & + & - \\
\hline DNA G + C content $(\mathrm{mol} \%)$ & $37.2-37.6$ & 36.0 & 36.8 & 33.8 \\
\hline
\end{tabular}

differences between its closest phylogenetic neighbours are shown in Table 2. The DNA G $+\mathrm{C}$ contents of the two isolates were determined by HPLC (UltiMate 3000, Dionex) (Mesbah et al., 1989). The G $+\mathrm{C}$ contents of strains $1-2^{\mathrm{T}}$ and $1-4$ were 37.2 and $37.6 \mathrm{~mol} \%$, respectively. The respiratory quinones were extracted and identified by HPLC as described by Komagata \& Suzuki (1987). Menaquinone-7 was detected as the predominant menaquinone.

DNA-DNA hybridization experiments were performed between strains $1-2^{\mathrm{T}}$ and 1-4 using the fluorometric method of Ezaki et al. (1989); the two strains shared a DNA-DNA relatedness of $94 \%$. All the evidence gathered in this study indicates that strains $1-2^{\mathrm{T}}$ and $1-4$ belong to the same species and that they can be differentiated from other species of the genus Pedobacter by a number of phenotypic characteristics. The low 16S rRNA gene sequence similarity of the novel strains with recognized species of the genus Pedobacter confirmed that strains $1-2^{\mathrm{T}}$ and 1-4 represent a novel species, for which the name Pedobacter glucosidilyticus sp. nov. is proposed with strain $1-2^{\mathrm{T}} \quad(=$ CCTCC $\mathrm{AB}$ $206110^{\mathrm{T}}=$ KCTC $\left.22438^{\mathrm{T}}\right)$ as the type strain.

\section{Description of Pedobacter glucosidilyticus sp. nov.}

Pedobacter glucosidilyticus (glu.co.si.di.ly'ti.cus. N.L. n. glucosidum glucoside; Gr. adj. lutikos able to loosen, able to dissolve; N.L. adj. lyticus - $a$-um dissolving; N.L. masc. adj. glucosidilyticus glucoside-dissolving).

Cells stain Gram-negative and are non-spore-forming, non-flagellated and non-motile rods of $0.6-0.7 \mu \mathrm{m}$ diameter and length $1.2-5.0 \mu \mathrm{m}$. Colonies on $0.1 \times$ TSA (Difco) plates are circular, convex, smooth, cream to pink coloured and 1.0-2.0 $\mathrm{mm}$ in diameter after incubation for 3 days at $28{ }^{\circ} \mathrm{C}$. Growth occurs from 15 to $37{ }^{\circ} \mathrm{C}$ (optimum, 
Table 2. Cellular fatty acid contents (\%) of strain $1-2^{\top}, P$. terricola KCTC $12876^{\top}$ and $P$. daechungensis KCTC $12637^{\top}$

Taxa: $1,1-2^{\mathrm{T}} ; 2$, Pedobacter terricola KCTC $12876^{\mathrm{T}} ; 3$, P. daechungensis KCTC $12637^{\mathrm{T}}$. All strains were grown on R2A agar for $72 \mathrm{~h}$ at $30{ }^{\circ} \mathrm{C}$. All data are from this study. - , Not detected; tr: trace $(<0.5 \%)$. Summed feature 3 comprised iso- $\mathrm{C}_{16: 1} \omega 7 c$ and/or $\mathrm{C}_{16: 1} \omega 6 c$. Fatty acids amounting to $<0.5 \%$ of the total fatty acids in all strains tested are not listed.

\begin{tabular}{|lccc|}
\hline Fatty acid & $\mathbf{1}$ & $\mathbf{2}$ & $\mathbf{3}$ \\
\hline Branched chain & & & \\
$\quad$ iso- $\mathrm{C}_{15: 0} 3-\mathrm{OH}$ & 2.2 & 2.8 & 1.2 \\
iso- $\mathrm{C}_{15: 0}$ & 31.5 & 30.7 & 20.4 \\
anteiso- $\mathrm{C}_{15: 0}$ & 4.9 & 4.2 & - \\
iso- $\mathrm{C}_{16: 0}$ & 0.9 & 1.8 & 2.2 \\
iso- $\mathrm{C}_{17: 0} 3-\mathrm{OH}$ & 13.1 & 12.3 & 7.3 \\
iso- $\mathrm{C}_{17: 1} \omega 9 c$ & 3.5 & 2.0 & 1.9 \\
anteiso- $\mathrm{C}_{17: 0}$ & $\operatorname{tr}$ & 2.7 & 2.0 \\
Unsaturated & & & \\
$\mathrm{C}_{15: 1} \omega 6 c$ & 3.3 & 2.3 & - \\
$\mathrm{C}_{16: 1} \omega 5 c$ & 1.3 & $\operatorname{tr}$ & 1.6 \\
Saturated & & & \\
$\mathrm{C}_{16: 0}$ & 5.4 & 7.6 & 9.6 \\
$\mathrm{C}_{15: 0}$ & - & - & 1.3 \\
Hydroxyl & & & \\
$\mathrm{C}_{16: 0} 3-\mathrm{OH}$ & 1.9 & - & 4.1 \\
Summed feature 3 & 12.5 & 11.5 & 13.4 \\
\hline
\end{tabular}

$30{ }^{\circ} \mathrm{C}$ ), but not at $42{ }^{\circ} \mathrm{C}$. Growth occurs from $\mathrm{pH} 5.5$ to 9 (optimum, 7.5). Growth occurs in the presence of $0-3 \%$ $\mathrm{NaCl}(\mathrm{w} / \mathrm{v})$ (optimum, $0.5 \%$ ), but not in the presence of $5 \% \mathrm{NaCl}$. No growth occurs on MacConkey agar. Oxidase, catalase, $\beta$-glucosidase and $\alpha$-fucosidase activities are present, but DNase, heparinase, amylase and urease activities are absent. Negative for nitrate reduction, production of $\mathrm{H}_{2} \mathrm{~S}$ and indole and for hydrolysis of tyrosine, casein and Tween 40. Flexirubin-type pigments are absent. Dextrin, $N$-acetyl-D-glucosamine, cellobiose, D-fructose, Dgalactose, gentiobiose, $\alpha$-D-glucose, $\alpha$-D-lactose, lactulose, maltose, D-mannose, sucrose, trehalose, turanose, pyruvic acid methyl ester, D-glucuronic acid and $\alpha$-D-glucose 1-phosphate are utilized in the Biolog GN2 microplate. Acid is produced from $N$-acetylglucosamine, arbutin, D-fructose, D-lactose and salicin. The predominant menaquinone is MK-7. The major fatty acids $(>10 \%)$ are iso$\mathrm{C}_{15: 0}$, iso- $\mathrm{C}_{17: 0} 3-\mathrm{OH}$ and summed feature 3 (comprising iso- $\mathrm{C}_{16: 1} \omega 7 c$ and/or $\left.\mathrm{C}_{16: 1} \omega 6 c\right)$. The DNA G $+\mathrm{C}$ content is 37.2-37.6 mol\% (HPLC).

The type strain, $1-2^{\mathrm{T}}$ (=CCTCC AB $206110^{\mathrm{T}}=\mathrm{KCTC}$ $22438^{\mathrm{T}}$ ), was isolated from soil of the Tietongmen area in Tibet, China. A reference strain, 1-4 (=CCTCC AB 206111), was isolated from the same source.

\section{Acknowledgements}

We are grateful to Dr Jung-Sook Lee of the Korean Collection for type Cultures (KCTC) for providing the type strains. This work was supported by the National Infrastructure of Natural Resources for Science and Technology program, Ministry of Science and Technology, the People's Republic of China (Grant No. 2005DKA21208).

\section{References}

An, D.-S., Kim, S.-G., Ten, L. N. \& Cho, C.-H. (2009). Pedobacter daechungensis sp. nov., from freshwater lake sediment in South Korea. Int J Syst Evol Microbiol 59, 69-72.

Baik, K.-S., Park, Y.-D., Kim, M.-S., Park, S.-C., Moon, E.-Y., Rhee, M.-S., Choi, J.-H. \& Seong, C.-N. (2007). Pedobacter koreensis sp. nov., isolated from fresh water. Int J Syst Evol Microbiol 57, 2079-2083.

Bowman, J. P. (2000). Description of Cellulophaga algicola sp. nov., isolated from the surfaces of Antarctic algae, and reclassification of Cytophaga uliginosa (ZoBell and Upham 1944) Reichenbach 1989 as Cellulophaga uliginosa comb. nov. Int J Syst Evol Microbiol 50, 18611868.

Chun, J., Lee, J.-H., Jung, Y., Kim, M., Kim, S., Kim, B. K. \& Lim, Y. W. (2007). EzTaxon: a web-based tool for the identification of prokaryotes based on $16 \mathrm{~S}$ ribosomal RNA gene sequences. Int J Syst Evol Microbiol 57, 2259-2261.

Ezaki, T., Hashimoto, Y. \& Yabuuchi, E. (1989). Fluorometric deoxyribonucleic acid-deoxyribonucleic acid hybridization in microdilution wells as an alternative to membrane filter hybridization in which radioisotopes are used to determine genetic relatedness among bacterial strains. Int J Syst Bacteriol 39, 224-229.

Gallego, V., García, M. T. \& Ventosa, A. (2006). Pedobacter aquatilis sp. nov., isolated from drinking water, and emended description of the genus Pedobacter. Int J Syst Evol Microbiol 56, 1853-1858.

Hwang, C. Y., Choi, D. H. \& Cho, B. C. (2006). Pedobacter roseus sp. nov., isolated from a hypertrophic pond, and emended description of the genus Pedobacter. Int J Syst Evol Microbiol 56, 1831-1836.

Komagata, K. \& Suzuki, K. (1987). Lipid and cell-wall analysis in bacterial systematics. Methods Microbiol 19, 161-207.

Kumar, S., Tamura, K. \& Nei, M. (2004). MEGA3: integrated software for molecular evolutionary genetics analysis and sequence alignment. Brief Bioinform 5, 150-163.

Kwon, S.-W., Kim, B. Y., Lee, K.-H., Jang, K.-Y., Seok, S.-J., Kwon, J.-S., Kim, W.-G. \& Weon, H. Y. (2007). Pedobacter suwonensis sp. nov., isolated from the rhizosphere of Chinese cabbage (Brassica campestris). Int J Syst Evol Microbiol 57, 480-484.

Lane, D. J. (1991). 16S/23S rRNA sequencing. In Nucleic Acid Techniques in Bacterial Systematics, pp.115-176. Edited by E. Stackebrandt \& M. Goodfellow. Chichester: Wiley.

Lee, H.-G., Im, W.-T., Oh, H.-M. \& Lee, S.-T. (2009). Pedobacter composti sp. nov., isolated from compost in South Korea. Int J Syst Evol Microbiol 59, 345-349.

Margesin, R., Spröer, C., Schumann, P. \& Schinner, F. (2003). Pedobacter cryoconitis sp. nov., a facultative psychrophile from alpine glacier cryoconite. Int J Syst Evol Microbiol 53, 1291-1296.

Mesbah, M., Premachandran, U. \& Whitman, W. B. (1989). Precise measurement of the $\mathrm{G}+\mathrm{C}$ content of deoxyribonucleic acid by highperformance liquid chromatography. Int J Syst Bacteriol 39, 159-167.

Muurholm, S., Cousin, S., Pauker, S., Brambilla, E. \& Stackebrandt, E. (2007). Pedobacter duraquae sp. nov., Pedobacter westerhofensis sp. nov., Pedobacter metabolipauper sp. nov., Pedobacter hartonius sp. nov. and Pedobacter steynii sp. nov., isolated from a hard-water rivulet. Int J Syst Evol Microbiol 57, 2221-2227.

Reichenbach, H. (1992). The order Cytophagales. In The Prokaryotes. A Handbook on the Biology of Bacteria: Ecophysiology, Isolation, 
Identification, Applications, 2nd edn, pp. 3631-3675. Edited by A. Balows, H. G. Trüper, M. Dworkin, W. Harder \& K. H. Schleifer. New York: Springer.

Roh, S. W., Quan, Z.-X., Nam, Y.-D., Chang, H.-W., Kim, K.-H., Kim, M.-K., Im, W.-T., Jin, L., Kim, S.-H. \& other authors (2008). Pedobacter agri sp. nov., from soil. Int J Syst Evol Microbiol 58, 1640-1643.

Shivaji, S., Chaturvedi, P., Reddy, G. S. N. \& Suresh, K. (2005). Pedobacter himalayensis sp. nov., from the Hamta glacier located in the Himalayan mountain ranges of India. Int J Syst Evol Microbiol $\mathbf{5 5}$ 1083-1088.

Smibert, R. M. \& Krieg, N. R. (1994). Phenotypic characterization. In Methods for General and Molecular Bacteriology, pp. 607-654. Edited by P. Gerhardt, R. G. E. Murray, W. A. Wood \& N. R. Krieg. Washington DC: American Society for Microbiology.

Steyn, P. L., Segers, P., Vancanneyt, M., Sandra, P., Kersters, K. \& Joubert, J. J. (1998). Classification of heparinolytic bacteria into a new genus, Pedobacter, comprising four species: Pedobacter heparinus comb. nov., Pedobacter piscium comb. nov., Pedobacter africanus sp. nov. and Pedobacter saltans sp. nov. Proposal of the family Sphingobacteriaceae fam. nov. Int J Syst Bacteriol 48, 165-177.

Ten, L. N., Liu, Q.-M., Im, W.-T., Lee, M., Yang, D.-C. \& Lee, S.-T.

(2006). Pedobacter ginsengisoli sp. nov., a novel DNase-producing bacterium isolated from soil of a ginseng field in South Korea. Int J Syst Evol Microbiol 56, 2565-2570.

Vanparys, B., Heylen, K., Lebbe, L. \& De Vos, P. (2005). Pedobacter caeni sp. nov., a novel species isolated from a nitrifying inoculum. Int J Syst Evol Microbiol 55, 1315-1318.

Yoon, J.-H., Lee, M.-H., Kang, S.-J., Park, S.-Y. \& Oh, T.-K. (2006). Pedobacter sandarakinus sp. nov., isolated from soil. Int J Syst Evol Microbiol 56, 1273-1277.

Yoon, M.-H., Lee, M.-H., Kang, S.-J., Park, S.-Y. \& Oh, T.-K. (2007a). Pedobacter panaciterrae sp. nov., isolated from soil in South Korea. Int J Syst Evol Microbiol 57, 381-386.

Yoon, J.-H., Ten, L. N., Im, W.-T. \& Lee, S.-T. (2007b). Pedobacter insulae sp. nov., isolated from soil. Int J Syst Evol Microbiol 57, 19992003.

Yoon, J.-H., Lee, M.-H., Kang, S.-J., Park, S.-Y. \& Oh, T.-K. (2007c). Pedobacter lentus sp. nov. and Pedobacter terricola sp. nov., isolated from soil. Int J Syst Evol Microbiol 57, 2089-2095.

Yoon, J.-H., Lee, M.-H., Kang, S.-J., Park, S.-Y. \& Oh, T.-K. (2007d). Pedobacter terrae sp. nov., isolated from soil. Int J Syst Evol Microbiol 57, 2462-2466.

Zimmermann, J. J., Langer, L. \& Cooney, C. L. (1990). Specific plate assay for bacterial heparinase. Appl Environ Microbiol 56, 3593-3594. 